\title{
GMR
}

\section{Genetic divergence in elite castor bean lineages based on TRAP markers}

\author{
K.S. Simões, S.A. Silva, E.L. Machado and M.S. Silva \\ Núcleo de Melhoramento Genético e Biotecnologia, \\ Centro de Ciências Agrárias Ambientais e Biológicas, \\ Universidade Federal do Recôncavo da Bahia, Cruz das Almas, BA, Brasil \\ Corresponding author: K.S. Simões \\ E-mail: karinesimoes01@hotmail.com
}

Genet. Mol. Res. 16 (3): gmr16039776

Received July 12, 2017

Accepted August 28, 2017

Published September 27, 2017

DOI http://dx.doi.org/10.4238/gmr16039776

Copyright (C) 2017 The Authors. This is an open-access article distributed under the terms of the Creative Commons Attribution ShareAlike (CC BY-SA) 4.0 License.

ABSTRACT. Castor bean (Ricinus communis L.) is a tropical plant
of great commercial interest and a potential source of biodiesel. The
development of genetically improved cultivars with high amounts
of oil in the seeds and low ricin toxicity is crucial to increase the
productivity of this crop. The use of TRAP (target region amplification
polymorphism) markers to develop elite lineages and study genetic
divergence is fundamental to advance the genetic improvement of this
species. The goal of this study was to evaluate the genetic divergence
among 40 elite lineages of R. communis, which belong to the NBIO-
UFRB Genetic Improvement Program, using TRAP markers involved
in the biosynthesis of oil and ricin. Total DNA was extracted and
quantified from the leaf tissue of the castor bean plants, and 70 TRAP
combinations (fixed and arbitrary primers) were used to genotype the
40 lineages. Of the 580 fragments amplified, 335 were polymorphic
(58\%). The genetic dissimilarity among the lineages was calculated by
the Jaccard dissimilarity index using the UPGMA grouping method.
A dendrogram was generated, and four groups formed, showing
divergence among the elite lineages that favors selection. The TRAP

Genetics and Molecular Research 16 (3): gmr16039776 
molecular markers were efficient at characterizing the genetic variability among the lineages and, because TRAP markers are functional markers involved in the biosynthesis of oil and ricin, they are important when studying the association between a marker and a candidate gene.

Key words: Oil biosynthesis; Ricin; Ricinus communis L.

\section{INTRODUCTION}

Castor bean (Ricinus communis L., $2 \mathrm{n}=2 \mathrm{x}=20$, Euphorbiaceae), an important nonedible oil seed, is predominantly cultivated in arid and semi-arid regions of the world and is used by industrial and agricultural industries.

The seeds of castor bean have around $35-55 \%$ oil, and the commercial standard is $44 \%$. The oil percentage of the seeds varies depending on the cultivation environment and the cultivar (Costa and Ramos, 2004). The hydroxylated fatty acid ricinoleic is approximately $80-90 \%$ of the total fatty acids, which gives castor bean oil (ricin oil) unique chemical and physical properties. Ricin oil is a renewable resource and raw material with various industrial applications (e.g., to manufacture paints, lubricants, cosmetics, pharmaceutical drugs, dyes, anilines, disinfectants, germicides, low-temperature lubricating oils, glues and adhesives, fungicide and insecticide bases, printing inks and varnishes, nylon and plastic), and more recently its use as a biodiesel has been explored (Mutlu and Meier, 2010).

Castor bean seeds have a high concentration of ricin protein. This protein is extremely toxic and considered one of the most lethal poisons if used intravenously or ingested. Ricin inhibits protein synthesis by interacting with ribosomes (Chan et al., 2010), and castor bean cake contains this toxic protein (Audi et al., 2005), which limits its use as animal food.

With the goals of increasing productivity and the amount of oil in the seeds (main product), as well as reducing ricin toxicity, it is necessary to have programs that genetically improve castor bean and develop elite lineages that meet the needs of the market and farmers. Now that some of these lineages have been developed, there is a need to study the genetic divergence among them. The genetic divergence among genotypes of any species can be evaluated with molecular markers, for example, target region amplification polymorphism (TRAP) markers.

TRAP markers are functional markers that allow combining fixed and specific primers with arbitrary primers (Hu and Vick, 2003). These markers have high levels of polymorphism, which makes them a promising option for the genotypification of germplasm and identification of genes related to desirable agronomic characteristics. Besides, TRAP markers optimize the genetic gains in genetic improvement programs and are a valuable tool used by these programs to study genetic divergence (Agarwal et al., 2008).

Different molecular markers have been used to estimate the degree of genetic divergence among genotypes of castor bean, for example, AFLP and simple sequence repeats (SSR) (Pecina-Quintero et al., 2013; Machado and Silva, 2013; Tan et al., 2013; Gálová et al., 2015; Machado et al., 2016), and RAPD and inter-simple sequence repeats (ISSR) (Silva et al., 2012; Machado et al., 2013; Tomar et al., 2014; Lakhani et al., 2015; Vivodík et al., 2015; Goodarzi et al., 2015; Kallamadi et al., 2015). However, functional TRAP markers have never been used to evaluate the genetic divergence in castor bean.

The integrity and efficiency of TRAP markers linked to disease resistance have been

Genetics and Molecular Research 16 (3): gmr16039776 
recorded in other crops, such as the common bean (Miklas et al., 2006). These markers have also been used to study the following: genetic maps of wheat (Liu et al., 2005), germplasm in spinach (Hu et al., 2007), and sugarcane (Suman et al., 2012); polymorphisms in cassava (Carmo et al., 2015); and the design and optimization of castor bean (Simões et al., 2017).

The elite lineages used in this study were obtained from crossing parents (BRS Nordestina, Sipeal, EBDA MPA-17, Mirante, and Paraguaçu) developed by the genetic improvement program at the Núcleo de Melhoramento Genético e Biotecnologia in the Universidade Federal do Recôncavo da Bahia (NBIO-UFRB), in the city of Cruz das Almas, Bahia, Brazil. The improvement method used was single seed descent (SSD) until the advanced $\mathrm{F}_{6}$ generation, when the plants were highly homozygous. This method allowed for individual selection of plants from the advanced population, with the formation of elite lineages.

The objective of the present study was to evaluate the genetic divergence among 40 elite lineages of $R$. communis L., which belong to the NBIO-UFRB genetic improvement program, using TRAP markers involved in the biosynthesis of oil and ricin.

\section{MATERIAL AND METHODS}

\section{Plant material}

Forty elite lineages of castor bean developed by the NBIO-UFRB genetic improvement program in Cruz das Almas, Bahia, Brazil, were used. The lineages were obtained by crossing the parents BRS Nordestina, Sipeal, EBDA MPA-17, Mirante, and Paraguaçu.

The municipality of Cruz das Almas is located at $12^{\circ} 40^{\prime} 19^{\prime \prime} \mathrm{S}, 39^{\circ} 06^{\prime} 23^{\prime \prime} \mathrm{W}$ and has an average elevation of $220 \mathrm{~m}$. The climate is sub-humid with an average annual rainfall of $1170 \mathrm{~mm}$ (varying between 900 and $1300 \mathrm{~mm}$ ). It rains the most from March to August and is drier from September to February. The average annual temperature is $24.1^{\circ} \mathrm{C}$ (Almeida, 1999).

The improvement method used to create the populations was SSD until the $\mathrm{F}_{6}$ generation when the degree of homozygosity is constant. SSD allowed for the individual selection of plants belonging to the advanced population $\left(\mathrm{F}_{6}\right)$. Of 240 lineages, 40 were selected, which suggests a selection pressure of approximately $17 \%$. The selection considered morphological characters, based on individuals that presented the best averages for oil content and seed weight.

The lineages were called the following: UFRB5, UFRB6, UFRB28, UFRB29, UFRB36, UFRB43, UFRB45, UFRB55, UFRB65, UFRB67, UFRB117, UFRB118, UFRB119, UFRB121, UFRB128, UFRB129, UFRB144, UFRB176, UFRB181, UFRB183, UFRB186, UFRB195, UFRB198, UFRB205, UFRB209, UFRB214, UFRB223, UFRB229, UFRB230, UFRB231, UFRB232, UFRB235, UFRB237, UFRB240, UFRB249, UFRB250, UFRB252, UFRB256, UFRB259, and UFRB265.

\section{DNA extraction}

Before extraction, the castor bean leaves were disinfected in $20 \%$ sodium hypochlorite, washed with distilled water, and stored in an ultra-freezer at $-80^{\circ} \mathrm{C}$. DNA was extracted following the protocol described by Doyle and Doyle (1990).

Approximately $300 \mathrm{mg}$ plant tissue was macerated with a mortar and pestle and liquid nitrogen. The macerated product was transferred to $2-\mathrm{mL}$ microtubes, and $700 \mu \mathrm{L}$ extraction

Genetics and Molecular Research 16 (3): gmr16039776 
buffer was added to each tube (2.0\% CTAB, $1.4 \mathrm{M} \mathrm{NaCl}, 0.1 \mathrm{M}$ Tris- $\mathrm{HCl}, \mathrm{pH} 8.0,20 \mathrm{mM}$ EDTA, $0.4 \%$ 2-mercaptoethanol, $1.0 \%$ PVP, and ultrapure water q.s.) at $65^{\circ} \mathrm{C}$. The samples were incubated in a water bath at $65^{\circ} \mathrm{C}$ for $45 \mathrm{~min}$, and homogenized every $15 \mathrm{~min}$. After $45 \mathrm{~min}, 700 \mu \mathrm{L}$ chloroform:isoamyl acid (24:1) was added to the samples. The material was gently homogenized and then centrifuged for $10 \mathrm{~min}$ at 10,000 rpm using a micro high-speed refrigerated centrifuge (VS-15000c, FNII). Subsequently, the supernatant was collected.

The extraction steps with chloroform:isoamyl acid were repeated to purify the material. Cold isopropyl acid $(400 \mu \mathrm{L})$ was added to the supernatant, which was equivalent to approximately $2 / 3$ of the volume collected.

The samples were incubated at $-20^{\circ} \mathrm{C}$ for $20 \mathrm{~min}$ and then centrifuged for $10 \mathrm{~min}$ at $12,000 \mathrm{rpm}$. The precipitate was resuspended in $600 \mu \mathrm{L}$ TE buffer $(10 \mathrm{mM}$ Tris-HCl, $\mathrm{pH} 8.0$, $1 \mathrm{mM}$ EDTA), $200 \mu \mathrm{L} 7.5 \mathrm{M}$ ammonium acetate was added, and the solution was incubated on ice for $15 \mathrm{~min}$.

The samples were then centrifuged for $15 \mathrm{~min}$ at $12,000 \mathrm{rpm}$. The supernatant was collected, and $800 \mu \mathrm{L}$ absolute ethanol was added. Following this, the samples were incubated for $1 \mathrm{~h}$ at $-20^{\circ} \mathrm{C}$, and then centrifuged for $10 \mathrm{~min}$ at $12,000 \mathrm{rpm}$. The precipitate was washed with $500 \mu \mathrm{L} 70 \%$ ethanol $(\mathrm{v} / \mathrm{v})$, centrifuged for $5 \mathrm{~min}$ at $12,000 \mathrm{rpm}$, and dried at room temperature. The precipitate was resuspended in TE buffer with $1 \mu \mathrm{L} \mathrm{RNase}(10 \mathrm{mg} / \mathrm{mL})$, and the samples were incubated in a water bath at $37^{\circ} \mathrm{C}$ for $1 \mathrm{~h}$. The samples were then stored in a freezer at $-20^{\circ} \mathrm{C}$.

\section{Quantification of the genomic DNA}

To evaluate the quality and amount of extracted DNA, $3 \mu \mathrm{LDNA}$ was added to $5 \mu \mathrm{L}$ dye (30\% glycerol and $0.25 \%$ bromophenol blue). The samples were applied to $0.8 \%$ agarose gel stained with ethidium bromide $(0.5 \mathrm{mg} / \mathrm{mL})$ and submitted to electrophorese for approximately 1 hand $20 \mathrm{~min}$ at $80 \mathrm{~V}$. The amount of DNA was evaluated by comparative analysis with a known concentration (lambda DNA; Invitrogen, Carlsbad, CA, USA). Before amplification, the samples were diluted in TE buffer to adjust the DNA concentration to $5 \mathrm{ng} / \mu \mathrm{L}$.

\section{Amplification of the genomic DNA with TRAP markers}

The amplification process used 28 fixed primers (Table 1) combined with 6 arbitrary primers (Table 2), for a total of 168 combinations. Seventy combinations that presented a good amplification pattern and sharp bands were selected.

The fixed primers were developed for the metabolic routes of fatty acid and ricin synthesis of the castor bean crop.

ESTs (expressed sequence tags) were retrieved from the NCBI database (National Center for Biotechnology Information, 2016) to design the fixed and direct primers using the Primer3 software (Rozen and Skaletsky, 2000). For the reverse, six arbitrary primers were used according to Li and Quiros (2001) and adapted by Hu and Vick (2003). The arbitrary primers comprise three selective nucleotides at the 3'-end, four AT-rich nucleotides (intron regions) or GC-rich nucleotides (exon regions) in the center, and 11 random nucleotides at the 5'-end.

The amplification reactions were made in a final volume of $15 \mu \mathrm{L}$ containing the following: $1 \mathrm{X}$ buffer (50 mM Tris-HCl, $20 \mathrm{mM} \mathrm{KCl),} 1.0 \mathrm{U}$ Taq DNA Polymerase (Invitrogen, Brazil); 2.0 $\mathrm{mM} \mathrm{MgCl}_{2} ; 0.2 \mathrm{mM}$ dNTP (Invitrogen, Brazil); $0.2 \mu \mathrm{M}$ primers (IDT); and 10 ng DNA.

Genetics and Molecular Research 16 (3): gmr16039776 
Table 1. Characterization of the fixed primers (target region amplification polymorphisms, TRAPs) used to genotype 40 lineages of castor bean.

\begin{tabular}{|c|c|c|c|c|}
\hline Primer & Sequence (5'-3') & $\% \mathrm{GC}$ & GenBank number & Gene/process \\
\hline \multicolumn{5}{|c|}{ Metabolic pathway of ricin } \\
\hline TRAP1 & CCACATCCAGCACCTTTTG & 52.63 & RCOM 0792550 & RIP superfamily \\
\hline TRAP2 & TGTGGAGCGTTGAGGATTC & 52.63 & RCOM 1110780 & RIP superfamily \\
\hline TRAP3 & TGCTCGCAGGCAAAGATAC & 52.63 & RCOM_1110790 & RIP superfamily \\
\hline TRAP4 & TGTCCCATATTTGCCAACG & 47.37 & RCOM_1180980 & Ricin superfamily \\
\hline TRAP5 & TGACGACTGCTCCTTCCAC & 57.89 & RCOM_1960510 & Ricin superfamily \\
\hline TRAP6 & GACGACTGCTCCTTCCACA & 57.89 & RCOM_2105270 & Ricin superfamily \\
\hline TRAP7 & TACGCACTATGGGCTCAGG & 57.89 & RCOM_2159810 & RIP superfamily \\
\hline TRAP8 & CCCTGATGTCGCTGCTAAA & 52.63 & RCOM_2159910 & RIP superfamily \\
\hline TRAP9 & AACCGCAAGTGGTCAAACA & 47.37 & RCOM_2160120 & RIP superfamily \\
\hline TRAP10 & $\begin{array}{l}\text { CGGGTGGCATCAGTTACAG } \\
\end{array}$ & 57.89 & RCOM_2160860 & RIP superfamily \\
\hline TRAP11 & $\begin{array}{l}\text { GGCGGATGCTATCTGTGAA } \\
\end{array}$ & 52.63 & RCOM_2160530 & RIP superfamily \\
\hline \multicolumn{5}{|c|}{ Metabolic pathway of fatty acid synthesis } \\
\hline TRAP12 & GACACCTTTGTTGCCATCG & 52.63 & RCOM_0040840 & LPLAT superfamily \\
\hline TRAP13 & ATCCCCAACAAGCACAACA & 47.37 & RCOM_0138550 & Ferritin superfamily \\
\hline TRAP14 & TTTCCTTGCTGCCTCTGTG & 52.63 & RCOM_0251360 & Ferritin superfamily \\
\hline TRAP15 & CCGTGATTCTGGTGGTGAG & 57.89 & RCOM_0612610 & PLN superfamily \\
\hline TRAP16 & TTACAACTGCGGCATCTCC & 52.63 & RCOM_0724080 & PLN2250 superfamily \\
\hline TRAP17 & TCCATCCCTTTCCATCCTC & 52.63 & RCOM_0853360 & LPLAT superfamily \\
\hline TRAP18 & TGGCATTTGCTTCCTTTGA & 42.11 & RCOM_0893800 & PLA2 subfamily \\
\hline TRAP19 & AATGCCAGCACCTACACCA & 52.63 & RCOM_0900600 & PAP2 superfamily \\
\hline TRAP20 & TTATCTTGGGAGGGGCTTG & 52.63 & RCOM_0925410 & PLN superfamily \\
\hline TRAP21 & ATCCTTCCAGGCAATCCAC & 52.63 & RCOM_1076810 & Ferritin superfamily \\
\hline TRAP22 & CACTCGCCTGTTCAGCACT & 57.89 & RCOM_1081890 & PLN superfamily \\
\hline TRAP23 & AGCAAGCCGCACCTAAGAT & 52.63 & RCOM_1403260 & RVT superfamily \\
\hline TRAP24 & GTCCAAGCAAAAGCCACCT & 52.63 & RCOM_1431520 & PLN superfamily \\
\hline TRAP25 & CCACCAATCCAACGCATAG & 52.63 & RCOM 1464650 & PLN superfamily \\
\hline TRAP26 & TTCATCTCCCTTGCCTTCC & 52.63 & RCOM_1502140 & Oleosin superfamily \\
\hline TRAP27 & CGAAATCCTCCTGCTCCTC & 52.63 & RCOM 1593790 & LPLAT superfamily \\
\hline TRAP28 & GCCACCATCTTCACCACAG & 57.89 & RCOM 1712710 & FABZ superfamily \\
\hline
\end{tabular}

The amplification was made with a Veriti ${ }^{\circledR}$ 96-well thermocycler (Applied Biosystems) and a touch-up program with the following cycle: $94{ }^{\circ} \mathrm{C}$ for $2 \mathrm{~min} ; 5$ cycles at $94^{\circ} \mathrm{C}$ for $45 \mathrm{~s}$, $35^{\circ} \mathrm{C}$ for $45 \mathrm{~s}$ and $72^{\circ} \mathrm{C}$ for $1 \mathrm{~min}$; followed by 30 cycles at $94^{\circ} \mathrm{C}$ for $45 \mathrm{~s}, 40^{\circ} \mathrm{C}$ for $45 \mathrm{~s}, 72^{\circ} \mathrm{C}$ for $1 \mathrm{~min}$; and a final extension of $72^{\circ} \mathrm{C}$ for $7 \mathrm{~min}$ (Carmo et al., 2015).

Electrophoresis was done on $4 \%$ agarose gel stained with ethidium bromide $(0.5 \mathrm{mg} /$ $\mathrm{mL}$ ). The amplified products were observed with a transilluminator and photographed with the Kodak Science digital system. The size of the fragments was estimated by visual comparison with a 100-bp Ladder (Invitrogen, Brazil).

Table 2. Arbitrary primers used to genotype the 40 lineages of castor bean.

\begin{tabular}{l|l}
\hline Name & Nucleotide sequence (3'-5') \\
\hline Arb1 & GACTGCGTACGAATTGAC \\
\hline Arb2 & GACTGCGTACGAATTTGA \\
\hline Arb3 & GACTGCGTACGAATTGCA \\
\hline Arb4 & GACTGCGTACGAATTAATT \\
\hline Arb5 & GACTGCGTACGAATTTGCC \\
\hline Arb6 & GACTGCGTACGAATTGACC \\
\hline
\end{tabular}

\section{Data analyses}

Because TRAP is a dominant marker, data were computed as absence $(0)$ and presence (1) of bands. The genetic diversity of the lineages was determined by the genetic dissimilarity 
matrix using the Jaccard index generated by the Genes program (Cruz, 2013). The Jaccard index is formulated as:

$$
I A B=A /(A+B+C)
$$

where $\mathrm{A}=$ same band for both individuals; $\mathrm{B}=$ presence of a band in individual 1 and absence in individual 2; $\mathrm{C}=$ absence of a band in individual 1 and presence in individual 2.

The hierarchical cluster analysis was performed using unweighted pair-group method averages (UPGMA) (Sneath and Sokal, 1973). All results were obtained using the programs $\mathrm{R}^{\circledR}$ 2.6.2 (http://www.r-project.org), STATISTICA version 7.1, and Genes (Cruz, 2013).

The dendrogram was constructed using the MEGA 5 software (Tamura et al., 2011), and the number of groups was defined using the package NbClust of R (Charrad et al., 2014) using the pseudo- $\mathrm{t}^{2}$ criterion; analyses were made with the statistical program $\mathrm{R}$ (R Core Team, 2017). The PIC (polymorphism information content) was calculated with the GENALEX 6.1 software (Peakall and Smouse, 2012).

\section{RESULTS AND DISCUSSION}

Of the 70 combinations of TRAP primers evaluated, 64 (91.0\%) presented a good amplification pattern for the 40 lineages of castor bean genotyped (Table 3). A total of 580 fragments were obtained, including $335(58.0 \%)$ that were polymorphic. The total number of fragments ranged from 3 to 15 , with an average of 1.23 per primer combination (Table 3 ). The polymorphic fragments ranged from 1 to 10 (11.0 to $100.0 \%$ polymorphic bands), and the molecular size ranged from 50 to $2000 \mathrm{bp}$. Figure 1 shows the DNA amplification of the elite lineages of castor bean using TRAP markers.

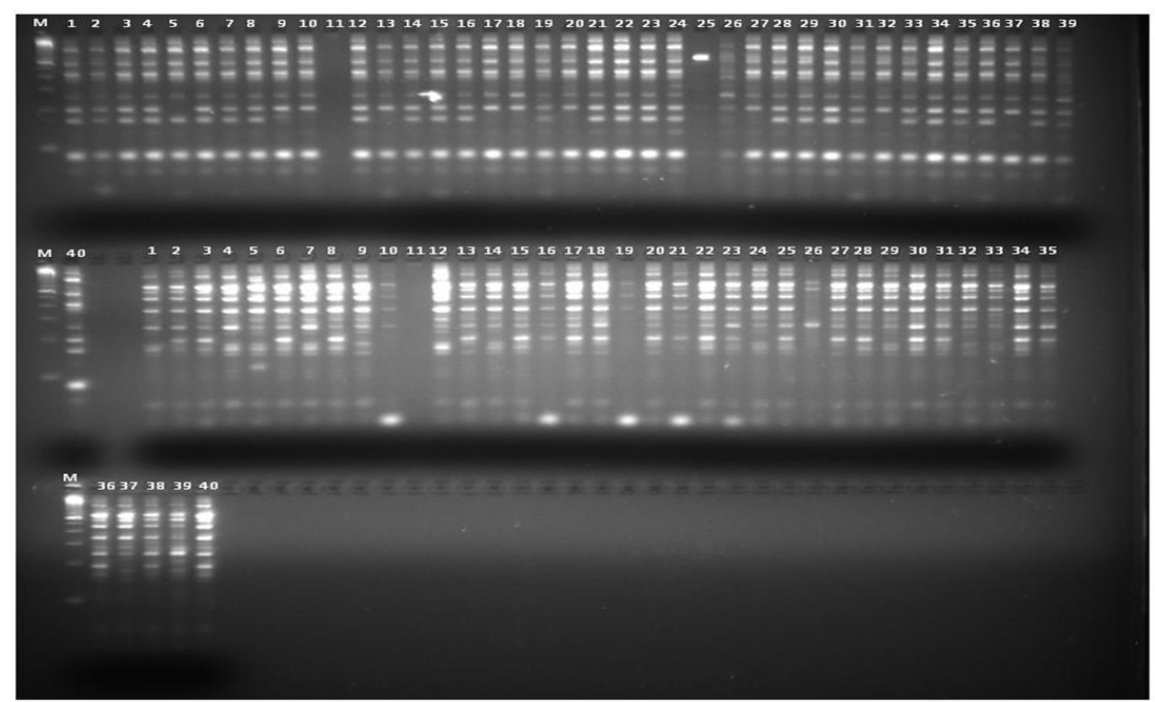

Figure 1. Electrophoretic profile, on $4 \%$ agarose gel, obtained from the amplification of the genomic DNA of 40 elite lineages of Ricinus communis L. (lanes 1-40) using TRAP primers. Lane M: 100-bp molecular weight marker and the combinations: 1 - TRAPC12+ARB5; 2 - TRAPC12+ARB6. 
Table 3. Combinations of target region amplification polymorphism (TRAP) primers selected to analyze the polymorphism in 40 lineages of castor bean.

\begin{tabular}{|c|c|c|c|c|}
\hline \multirow[t]{2}{*}{ Combinations } & \multicolumn{2}{|c|}{ No. of fragments } & \multirow[t]{2}{*}{ Polymorphism (\%) } & \multirow[t]{2}{*}{ PIC } \\
\hline & Total & Polymorphism & & \\
\hline Trap1 x Arb1 & 9 & 3 & 33 & 0.03 \\
\hline Trap1 x Arb5 & 12 & 3 & 25 & 0.30 \\
\hline Trap1 x Arb6 & 13 & 3 & 23 & 0.08 \\
\hline Trap2 x Arb1 & 9 & 1 & 11 & 0.21 \\
\hline Trap2 x Arb3 & 10 & 4 & 40 & 0.30 \\
\hline Trap2 x Arb4 & 9 & 4 & 44 & 0.37 \\
\hline Trap2 x Arb6 & 8 & 4 & 50 & 0.37 \\
\hline Trap3 x Arb4 & 7 & 5 & 71 & 0.17 \\
\hline Trap4 x Arb6 & 9 & 5 & 55 & 0.10 \\
\hline Trap5 x Arb6 & 7 & 1 & 14 & 0.38 \\
\hline Trap6 x Arb2 & 7 & 5 & 71 & 0.20 \\
\hline Trap6 x Arb6 & 6 & 6 & 100 & 0.30 \\
\hline Trap7 x Arb1 & 5 & 3 & 60 & 0.15 \\
\hline Trap7 x Arb2 & 5 & 3 & 60 & 0.26 \\
\hline Trap7 x Arb3 & 6 & 3 & 50 & 0.27 \\
\hline Trap8 x Arb2 & 6 & 4 & 66 & 0.16 \\
\hline Trap8 x Arb5 & 7 & 5 & 71 & 0.20 \\
\hline Trap9 x Arb4 & 4 & 4 & 100 & 0.24 \\
\hline Trap9 x Arb6 & 9 & 7 & 77 & 0.16 \\
\hline Trap10 x Arb3 & 10 & 4 & 40 & 0.16 \\
\hline Trap10 x Arb4 & 5 & 5 & 100 & 0.26 \\
\hline Trap10 x Arb5 & 8 & 8 & 100 & 0.23 \\
\hline Trap10 x Arb6 & 6 & 5 & 83 & 0.29 \\
\hline Trap11 x Arb2 & 9 & 2 & 22 & 0.09 \\
\hline Trap11 x Arb3 & 8 & 5 & 62 & 0.11 \\
\hline Trap11 x Arb6 & 7 & 3 & 43 & 0.28 \\
\hline Trap12 x Arb2 & 7 & 4 & 57 & 0.09 \\
\hline Trap12 x Arb3 & 8 & 3 & 38 & 0.30 \\
\hline Trap12 x Arb5 & 9 & 6 & 67 & 0.22 \\
\hline Trap12 x Arb6 & 11 & 10 & 91 & 0.24 \\
\hline Trap13 x Arb1 & 8 & 5 & 63 & 0.33 \\
\hline Trap13 x Arb2 & 9 & 7 & 78 & 0.31 \\
\hline Trap13 x Arb3 & 12 & 5 & 42 & 0.31 \\
\hline Trap13 x Arb4 & 10 & 5 & 50 & 0.24 \\
\hline Trap13 x Arb5 & 12 & 6 & 50 & 0.23 \\
\hline Trap13 x Arb6 & 8 & 3 & 38 & 0.23 \\
\hline Trap14 x Arb1 & 4 & 3 & 75 & 0.33 \\
\hline Trap14 x Arb4 & 3 & 3 & 100 & 0.21 \\
\hline Trap14 x Arb6 & 8 & 5 & 63 & 0.27 \\
\hline Trap15 x Arb2 & 7 & 6 & 86 & 0.27 \\
\hline Trap15 x Arb5 & 13 & 4 & 31 & 0.18 \\
\hline Trap16 x Arb2 & 9 & 4 & 44 & 0.14 \\
\hline Trap16 x Arb3 & 8 & 3 & 38 & 0.28 \\
\hline Trap16 x Arb4 & 8 & 4 & 50 & 0.22 \\
\hline Trap17 x Arb2 & 7 & 2 & 29 & 0.24 \\
\hline Trap17 x Arb6 & 6 & 5 & 83 & 0.32 \\
\hline Trap18 x Arb2 & 7 & 3 & 43 & 0.25 \\
\hline Trap18 x Arb3 & 6 & 4 & 67 & 0.27 \\
\hline Trap19 x Arb3 & 9 & 8 & 89 & 0.21 \\
\hline Trap19 x Arb5 & 9 & 3 & 33 & 0.29 \\
\hline Trap20 x Arb1 & 7 & 4 & 57 & 0.25 \\
\hline Trap20 x Arb3 & 6 & 6 & 100 & 0.25 \\
\hline Trap20 x Arb4 & 4 & 2 & 50 & 0.26 \\
\hline Trap21 x Arb2 & 7 & 6 & 86 & 0.22 \\
\hline Trap21 x Arb5 & 9 & 7 & 78 & 0.29 \\
\hline Trap22 x Arb1 & 10 & 7 & 70 & 0.33 \\
\hline Trap22 x Arb6 & 15 & 5 & 33 & 0.31 \\
\hline Trap23 x Arb2 & 6 & 4 & 67 & 0.24 \\
\hline Trap23 x Arb3 & 10 & 5 & 50 & 0.20 \\
\hline Trap24 x Arb1 & 12 & 4 & 33 & 0.33 \\
\hline Trap24 x Arb5 & 10 & 5 & 50 & 0.27 \\
\hline Trap25 x Arb1 & 11 & 5 & 45 & 0.18 \\
\hline Trap25 x Arb4 & 8 & 8 & 100 & 0.29 \\
\hline Trap26 x Arb2 & 7 & 6 & 86 & 0.27 \\
\hline Trap26 x Arb4 & 7 & 3 & 43 & 0.32 \\
\hline Trap27 x Arb1 & 12 & 6 & 50 & 0.32 \\
\hline Trap27 x Arb2 & 10 & 9 & 90 & 0.20 \\
\hline Trap27 x Arb3 & 10 & 8 & 80 & 0.33 \\
\hline Trap28 x Arb2 & 11 & 9 & 82 & 0.31 \\
\hline Trap $28 \times$ Arb4 & 10 & 10 & 100 & 0.28 \\
\hline Averages & 8.3 & 4.8 & & 0.24 \\
\hline
\end{tabular}

$\mathrm{PIC}=$ polymorphism information content.

Genetics and Molecular Research 16 (3): gmr16039776 
Studies using TRAP markers have been conducted with other crops: guaraná (total number of polymorphic bands ranged from 12 to 33, with 79\% polymorphism, and fragment size between 100 and 800 bp) (Da Silva et al., 2016); Dendrobium (genotyped with 13 TRAP markers, obtaining 510 fragments, including 500 polymorphic fragments, and $97.8 \%$ polymorphism) (Feng et al., 2015); Diospyros kaki (genotyped with 36 combinations of TRAP primers with an amplification of 2184 fragments, of which 2072 were polymorphic fragments and $94.87 \%$ polymorphism) (Luo et al., 2013); and sugarcane (21 TRAP combinations, for sucrose synthesis, with an amplification of 340 polymorphic fragments, with an average of 16.2 fragments, and 9 TRAP combinations for drought tolerance, resulting in 155 polymorphic fragments, with an average of 17.2 fragments per primer combination) (Creste et al., 2010). These studies corroborate the results obtained for castor bean, because they show that TRAP markers are highly polymorphic and appropriate for studying genetic divergence and other applications, for example, mapping associations and QTLs. It is worth noting that TRAP markers for castor bean, developed in this study, have never been published.

Variations in DNA sequences lead to greater genetic diversity. The PIC varied from 0.03 (Trap1 x Arb1 combination) to 0.33 (Trap5 x Arb6 combination), with an average of 0.24 (Table 3).

Considering that TRAP markers are dominant, the maximum PIC value observed was 0.50 ; therefore, the closer to this value, the greater the discriminatory power of the primer. Thus, 35 TRAP combinations had a PIC above 0.25 (Table 3), with higher discrimination power among the genotypes evaluated.

The PIC values found for castor bean are comparable to those for the TRAP technique used for cassava, where PIC values ranged from 0.03 to 0.38 , with an average of 0.23 , for 31 TRAP combinations (Carmo et al., 2015). For other crops, higher PIC values were found: guaraná, PIC ranged from 0.29 to 0.36 , average of 0.33 , for 5 TRAP combinations (Da Silva et al., 2016), and sunflower, PIC ranged from 0.02 to 0.50 , average of 0.39 , for 12 TRAP combinations (Yue et al., 2009).

Besides, it was observed that the PIC values for TRAP markers vary based on the arbitrary primer. In general, the Arb2 and Arb6 primers had the highest number of fragments per marker, with averages of 14.25 (Arb2) and 16.14 (Arb6), and polymorphic fragment averages of 4.93 (Arb2) and 8.86 (Arb6) (Table 4). However, Arb4 had a higher percentage of polymorphism $(70.67 \%)$.

Table 4. Polymorphism and the total number of fragments concerning the arbitrary primers with 70 TRAP
combinations.
\begin{tabular}{l|c|c|c|c|c} 
Arbitrary primer & Total No. of fragments & Average & Total & Average & \\
\cline { 2 - 6 } & 87 & 15.90 & 41 & 4.10 & 4.93 \\
\hline Arb 1 & 117 & 14.25 & 74 & 4.83 & 63.24 \\
\hline Arb 2 & 99 & 15.23 & 58 & 9.83 & 70.67 \\
\hline Arb 3 & 75 & 12.50 & 47 & 9.40 & 5.86 \\
\hline Arb 5 & 89 & 17.80 & 62 & & 54.87 \\
\hline Arb 6 & 113 & 16.14 & & & \\
\hline
\end{tabular}

The genetic distance, calculated by the amount of discordance between lineages (for the genetic dissimilarity of the 40 lineages), varied between 0.20 and 0.98 , with an average of 0.66 . The high average genetic distance $(0.66)$ reveals significant genetic dissimilarity among the elite lineages evaluated, which is important for decision making within the genetic improvement program for the species.

Genetics and Molecular Research 16 (3): gmr16039776 
The most genetically similar lineages were UFRB45 and UFRB55 (genetic distance of 0.20) and the most dissimilar were the lineages UFRB214 and UFRB252 (genetic distance of 0.98). Furthermore, the lineages UFRB5 and UFRB214 (0.97), UFRB121 and UFRB 214 (0.96), and UFRB214 and UFRB240 (0.96) stood out for having high genetic distance values.

Based on the dendrogram obtained, it is possible to separate the 40 lineages of castor bean into four groups (Figure 2): Group 1 (UFRB45, UFRB55, UFRB43, UFRB65, UFRB29, UFRB231, UFRB240, UFRB198, UFRB186, UFRB195, UFRB144, UFRB36, UFRB250, UFRB121, UFRB118, UFRB67, UFRB128, UFRB129, UFRB265, UFRB28, UFRB223, UFRB229, UFRB230, UFRB205, UFRB209, UFRB117, UFRB235, UFRB119, UFRB181, UFRB176, UFRB183, UFRB252, UFRB232, UFRB237, UFRB249); Group 2 (UFRB5, UFRB6); Group 3 (UFRB256, UFRB259); and Group 4 (UFRB214).

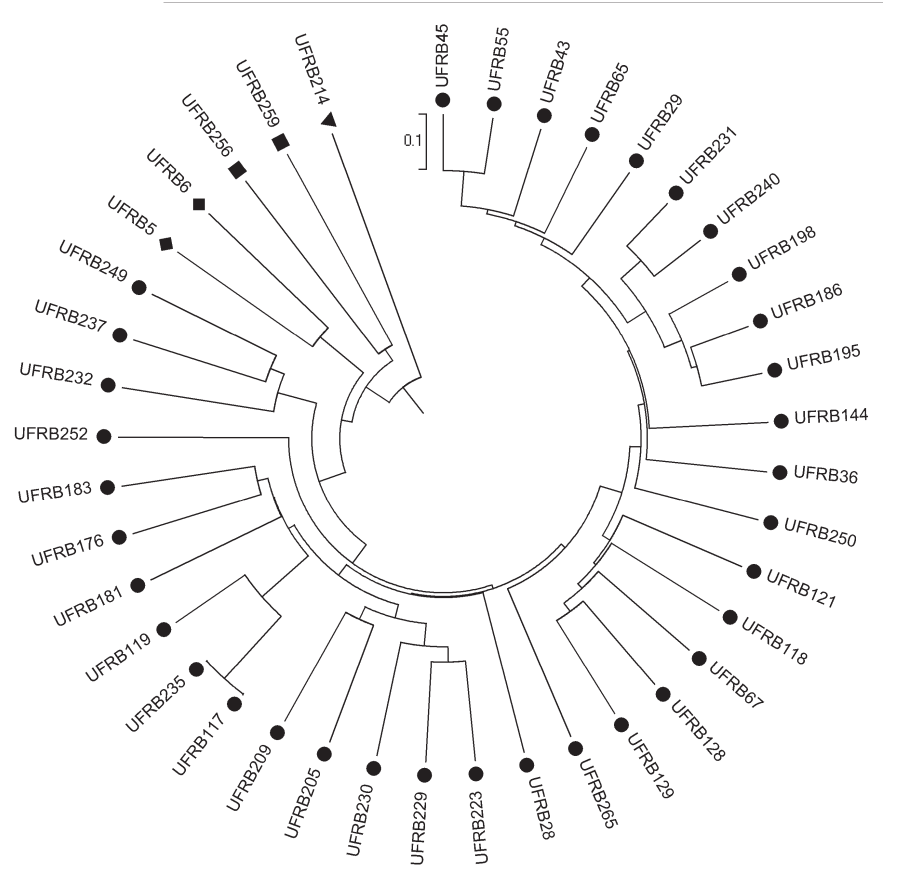

Figure 2. Genetic dissimilarity among 40 elite lineages of the active germplasm bank (AGB) of castor bean. Circles, group 1; lozenges, group 2; squares, group 3; and triangles, group 4.

Group 1 represents $87.5 \%$ of the 40 lineages evaluated and groups 2 and 3 represent $10 \%$. Group 4 is notable for having only one lineage, UFRB 214, which corresponds to $2.5 \%$ of the lineages evaluated. These results show the genetic dissimilarity among the elite lineages of castor bean, especially UFRB 214 that had the greatest dissimilarity with the others. This is an important fact for the genetic improvement program of the species because all the genotypes constitute advanced generations from self-fertilization with high degrees of homozygosity.

Studies of genetic divergence of accessions and cultivars of castor bean using molecular markers have been conducted; however, articles with improved, advanced (6 generations of self-fertilization), highly homozygous (elite lineages) populations that use TRAP markers have not been published.

Genetics and Molecular Research 16 (3): gmr16039776 
Genetic divergence studies of castor bean cultivars have been made using RAPD markers by the following: Machado et al. (2013) genotyped 15 cultivars and obtained 5 distinct groups; Silva et al. (2012) studied 5 cultivars and observed 2 distinct groups; Lakhani et al. (2015) evaluated 13 accessions and, like the previous authors, identified 2 groups; and Vivodík et al. (2015) evaluated 32 genotypes and also found 2 groups.

Another dominant marker, ISSR, was used to study genetic divergence of castor bean by Goodarzi et al. (2015), who found 4 groups among 12 accessions, and Wang et al. (2013), who evaluated 39 genotypes that separated into 4 groups.

In addition, SSR were used to evaluate genetic divergence of castor bean: Machado et al. (2016) studied 32 improved genotypes (F4), which formed 5 distinct groups; Gálová et al. (2015), for 60 accessions, found 6 groups; and Tan et al. (2013), with 53 clones, also found 6 groups.

The number of groups formed in this study, compared to the studies cited above, shows the efficiency of TRAP markers at detecting genetic variability of castor bean. Also, it is worth noting that the methodology of improvement and self-fertilization of the population resulted in divergent lineages that formed 4 groups.

TRAP markers are efficient when studying genetic variability of castor bean and are an important tool for genetic studies of the species.

Further, because TRAPs are functional markers involved in the biosynthesis of oil and ricin, they are promising for studies of associations between a marker and candidate gene.

The elite lineages in this study, developed by the UFRB Genetic Improvement Program, showed genetic divergence among them (especially lineage 214), a favorable result for the success of the program.

\section{Conflicts of interest}

The authors declare no conflict of interest.

\section{ACKNOWLEDGMENTS}

Research supported by Coordenação de Aperfeiçoamento de Pessoal de Nível Superior (CAPES), Petrobrás Biocombustível, and Agência Nacional de Petróleo, Gas Natural e Biocombustícel (ANP).

\section{REFERENCES}

Agarwal M, Shrivastava N and Padh H (2008). Advances in molecular marker techniques and their applications in plant sciences. Plant Cell Rep. 27: 617-631. https://doi.org/10.1007/s00299-008-0507-z

Almeida AO (1999). Informações meteorológicas do CNP: Mandioca e Fruticultura tropical. Cruz das Almas, BA: EMBRAPA - CNPMF. 35.

Audi J, Belson M, Patel M, Schier J, et al. (2005). Ricin poisoning: a comprehensive review. JAMA 294: 2342-2351. https://doi.org/10.1001/jama.294.18.2342

Carmo CD, Santos DB, Alves LB, Oliveira GAF, et al. (2015). Development of TRAP (target region amplification polymorphism) as new tool for molecular genetic analysis in cassava. Plant Mol. Biol. Report. 33: 1953-1966. https:// doi.org/10.1007/s11105-015-0887-5

Chan AP, Crabtree J, Zhao Q, Lorenzi H, et al. (2010). Draft genome sequence of the oilseed species Ricinus communis. Nat. Biotechnol. 28: 951-956. https://doi.org/10.1038/nbt.1674

Charrad M, Ghazzali N, Boiteau V and Niknafs A (2014). NbClust: An R package for determining the relevant number of clusters in a data set. J. Stat. Softw. 61: 1-36. https://doi.org/10.18637/jss.v061.i06

Genetics and Molecular Research 16 (3): gmr16039776 
Costa HM and Ramos VD (2004). Efeito do óleo de mamona em composições de borracha natural contendo sílica. Polímeros: Ciênc. Tecnol 14: 46-50.

Creste S, Accoroni KAG, Pinto LR, Vencovsky R, et al. (2010). Genetic variability among sugarcane genotypes based on polymorphisms in sucrose metabolism and drought tolerance genes. Euphytica 172: 435-446. https://doi.org/10.1007/ $\underline{\text { s10681-009-0078-2 }}$

Cruz CD (2013). GENES - a software package for analysis in experimental statistics and quantitative genetics. Acta Sci. Agron. 35: 271-276. https://doi.org/10.4025/actasciagron.v35i3.21251

Da Silva EF, de Sousa SB, da Silva GF, Sousa NR, et al. (2016). TRAP and SRAP markers to find genetic variability in complex polyploid Paullinia cupana var. sorbilis. Plant Gene 6: 43-47. https://doi.org/10.1016/j.plgene.2016.03.005

Doyle JJ and Doyle JL (1990). A rapid total DNA preparation procedure for fresh plant tissue. Focus 12: 13-15.

Feng S, He R, Yang S, Chen Z, et al. (2015). Start codon targeted (SCoT) and target region amplification polymorphism (TRAP) for evaluating the genetic relationship of Dendrobium species. Gene 567: 182-188. https://doi.org/10.1016/j. gene.2015.04.076

Gálová Z, Vivodík M, Balážová Z and Hlozáková TK (2015). Identification and differentiation of Ricinus communis L. using SSR markers. Potravinárstvo 9: 556-561. https://doi.org/10.5219/516

Goodarzi F, Darvishzadeh R and Hassani A (2015). Genetic analysis of castor (Ricinus communis L.) using ISSR markers. $J P M B$ 3: 18-34.

Hu J and Vick BA (2003). Target region amplification polymorphism: a novel marker technique for plant genotyping. Plant Mol. Biol. Report. 2: 289-294. https://doi.org/10.1007/BF02772804

Hu J, Mou B and Vick BA (2007). Genetic diversity of 38 spinach (Spinacia oleracea L.) germplasm accessions and 10 commercial hybrids assessed by TRAP markers. Genet. Resour. Crop Evol. 54: 1667-1674. https://doi.org/10.1007/ s10722-006-9175-4

Kallamadi PR, Nadigatla VPRGR and Mulpuri S (2015). Molecular diversity in castor (Ricinus communis L.). Ind. Crops Prod. 66: 271-281. https://doi.org/10.1016/j.indcrop.2014.12.061

Lakhani HN, Patel SV, Bodar NP and Golakiya BA (2015). RAPD analysis of genetic diversity of castor bean (Ricinus communis L.). Int. J. Curr. Microbiol. Appl. Sci. 4: 696-703.

Li G and Quiros CF (2001). Sequence-related amplified polymorphism (SRAP), a new marker system based on a simple PCR reaction: its application to mapping and gene tagging in Brassica. Theor. Appl. Genet. 103: 455-461. https://doi. org $/ 10.1007 / \mathrm{s} 001220100570$

Liu ZH, Anderson JA, Hu J, Friesen TL, et al. (2005). A wheat intervarietal genetic linkage map based on microsatellite and target region amplified polymorphism markers and its utility for detecting quantitative trait loci. Theor. Appl. Genet. 111: 782-794. https://doi.org/10.1007/s00122-005-2064-y

Luo C, Zhang F, Zhang QL, Guo DY, et al. (2013). Characterization and comparison of EST-SSR and TRAP markers for genetic analysis of the Japanese persimmon Diospyros kaki. Genet. Mol. Res. 12: 2841-2851. https://doi. org/10.4238/2013.January. 9.3

Machado EL and Silva AS (2013). Desenho e validação de iniciadores microssatélites SSR para mamoneira. Pesqui. Agropecu. Bras. 48: 1457-1463. https://doi.org/10.1590/S0100-204X2013001100006

Machado EL, SilvaAS, Santos AS, Bastos LA, et al. (2013). Dissimilaridade genética entre cultivares de mamoneira por meio de marcadores RAPD. Pesqui. Agropecu. Bras. 48: 342-345. https://doi.org/10.1590/S0100-204X2013000300014

Machado EL, Silva SA, Fernandes LS and Brasileiro HS (2016). Genetic variability and homozygosity in a F4 castor bean population by microsatellite markers. Bragantia $75: 307-313$. https://doi.org/10.1590/1678-4499.536

Miklas PN, Hu J, Grunwald NJ and Larsen KM (2006). Potential application of TRAP (Targeted Region Amplified Polymorphism) markers for mapping and tagging disease resistance traits in common bean. Crop Sci. 46: 910-916. https://doi.org/10.2135/cropsci2005.08-0242

Mutlu $\mathrm{H}$ and Meier MAR (2010). Castor oil as a renewable resource for the chemical industry. Eur. J. Lipid Technol. 112: 10-30. https://doi.org/10.1002/ejlt.200900138

National Center for Biotechnology Information (NCBI) (2016). Shotgun Assembly Sequences: Genome (WGS) and Transcriptome (TSA). Available at [http://www.ncbi.nlm.nih.gov/Traces/wgs/?val=AASG02]. Accessed April 20, 2016.

Peakall R and Smouse PE (2012). GenAlEx 6.5: genetic analysis in Excel. Population genetic software for teaching and research--an update. Bioinformatics 28: 2537-2539. https://doi.org/10.1093/bioinformatics/bts460

Pecina-Quintero V, Anaya-López JL, Núnez-Colín CA, Zamarripa-Colmenero A, et al. (2013). Assessing the genetic diversity of castor bean from Chiapas, México using SSR and AFLP markers. Ind. Crops Prod. 41: 134-143. https:// doi.org/10.1016/j.indcrop.2012.04.033

R Core Team (2017). R: A language and environment for statistical computing. R Foundation for Statistical Computing, Vienna, Austria. Available at [http://www.R-project.org]. Accessed April 10, 2017.

Genetics and Molecular Research 16 (3): gmr16039776 
Rozen S and Skaletsky HJ (2000). Primer 3 on the www for general users and for biologist programmers. In: Bioinformatics methods and protocols: Methods in molecular biology (Krawetz S and Misener S, eds.). Humana Press, Totowa, 365-386.

Silva AS, Cerqueira LS, Vilarinhos AD, Amorim EP, et al. (2012). Variabilidade genética em cultivares de mamona por meio de marcadores RAPD. Magistra 24: 341-347.

Simões KS, Silva SA, Machado EL and Brasileiro HS (2017). Development of TRAP primers for Ricinus communis L. Genet. Mol. Res. 16: 1-13. https://doi.org/10.4238/gmr16029647

Sneath PHA and Sokal RR (1973). Numerical taxonomy. Freeman, San Francisco.

Suman A, Ali K, Arro J, Parco AS, et al. (2012). Molecular Diversity Among Members of the Saccharum Complex Assessed Using TRAP Markers Based on Lignin-Related Genes. Bioenerg. Res. 5: 197-205. https://doi.org/10.1007/ s12155-011-9123-9

Tamura K, Peterson D, Peterson N, Stecher G, et al. (2011). MEGA5: molecular evolutionary genetics analysis using maximum likelihood, evolutionary distance, and maximum parsimony methods. Mol. Biol. Evol. 28: 2731-2739. https://doi.org/10.1093/molbev/msr121

Tan M, Yan M, Wang L, Yan X, et al. (2013). Replication of pistillate plants of Ricinus communis L. and investigation of the sex stability and genetic variation of the somaclones. Ind. Crops Prod. 50: 50-57. https://doi.org/10.1016/j. indcrop.2013.06.042

Tomar RS, Parakhia MV, Kavani RH, Dobariya KL, et al. (2014). Characterization of castor (Ricinus communis L.) genotypes using different markers. Res. J. Biotechnol. 9: 6-13.

Vivodík M, Balážová Z, Gálová Z and Hlozáková TK (2015). Evaluation of molecular diversity of new castor lines (Ricinus communis L.) using random amplified polymorphic DNA markers. Hortic. Biotechnol. Res. 1: 1-4.

Wang C, Li GR, Zhang ZY, Peng M, et al. (2013). Genetic diversity of castor bean (Ricinus communis L.) in Northeast China revealed by ISSR markers. Biochem. Syst. Ecol. 51: 301-307. https://doi.org/10.1016/j.bse.2013.09.017

Yue B, Cai X, Vick BA and Hu J (2009). Genetic Diversity and Relationships among 177 Public Sunflower Inbred Lines Assessed by TRAP Markers. Crop Sci. 49: 1242-1249. https://doi.org/10.2135/cropsci2008.08.0471

Genetics and Molecular Research 16 (3): gmr16039776 